- Domingos Dias Cicarelli

- Fábio Ely Martins Benseñor

- Joaquim Edson Vieira

\section{ABSTRACT}

CONTEXT AND OBJECTIVE: Systemic inflammatory response syndrome (SIRS) is a very common condition among critically ill patients. SIRS, sepsis, septic shock and multiple organ dysfunction syndrome (MODS) can lead to death. Our aim was to investigate the efficacy of a single dose of dexamethasone for blocking the progression of systemic inflammatory response syndrome.

DESIGN AND SETTING: Prospective, randomized, double-blind, single-center study in a postoperative intensive care unit (Surgical Support Unit) at Hospital das Clínicas, Faculdade de Medicina, Universidade de São Paulo.

METHODS: The study involved 29 patients with SIRS. All eligible patients were prospectively randomized to receive either a single dose of $0.2 \mathrm{mg} / \mathrm{kg}$ of dexamethasone or placebo, after SIRS was diagnosed. The patients were monitored over a seven-day period using Sequential Organ Failure Assessment score (SOFA).

RESULTS: The respiratory system showed an improvement on the first day after dexamethasone was administered, demonstrated by the improved $\mathrm{PaO}_{2} / \mathrm{FiO}_{2}$ ratio $(p<0.05)$. The cardiovascular system of patients requiring vasopressor therapy also improved over the first two days, with a better evolution in the dexamethasone group $(p<0.05)$. Non-surviving patients presented higher lactate assays than did survivors $(p<0.05)$ during this period.

CONCLUSIONS: Dexamethasone enhanced the effects of vasopressor drugs and evaluation of the respiratory system showed improvements (better $\mathrm{PaO}_{2} / \mathrm{FiO}_{2}$ ratio), one day after its administration. Despite these improvements, the single dose of dexamethasone did not block the evolution of SIRS

KEY WORDS: Sepsis syndrome. Sepsis. Inflammation. Adrenal cortex hormones. Dexamethasone.

\title{
Effects of single dose of dexamethasone on patients with systemic inflammatory response
}

\author{
Surgical Support Unit, Anesthesia Division, Department of Surgery, \\ Hospital das Clínicas, Faculdade de Medicina, Universidade de São \\ Paulo, São Paulo, Brazil
}

INTRDDUCTION

Systemic inflammatory response syndrome (SIRS) is a very common condition among critically ill patients. It occurs frequently in the postoperative period, with or without infection. SIRS may be related to trauma, burns, pancreatitis or pulmonary diseases, leading to acute lung injury (ALI) and acute distress respiratory syndrome (ARDS). ${ }^{1}$ SIRS can be defined by two or more symptoms such as fever (body temperature $\left.>38^{\circ} \mathrm{C}\right)$ or hypothermia $\left(<36^{\circ} \mathrm{C}\right)$, tachycardia ( $>90$ beats $/ \mathrm{min}$ ), tachypnea ( $>20$ breaths $/ \mathrm{min}$ ) or hyperventilation $\left(\mathrm{PaCO}_{2}<32\right.$ torr), and abnormal white blood cell counts $(>12,000 \mathrm{cells} / \mu \mathrm{l}$ or $<4,000 \mathrm{cells} / \mu \mathrm{l})$ or immature neutrophils (bands > 10\%). ${ }^{1,2}$

SIRS, sepsis, septic shock and multiple organ dysfunction syndrome (MODS) are strongly related. The patient's progression through this sequence often leads to death. However, some patients with SIRS develop MODS without diagnosed infection or sepsis. ${ }^{3}$ Sepsis is defined as a condition in which the patient displays the SIRS criteria as well as a documented or a suspected infection. Severe sepsis is defined as sepsis with organ dysfunction, inadequate perfusion or hypotension (systolic blood pressure $<90 \mathrm{mmHg}$ or a reduction $\geq 40 \mathrm{mmHg}$ from the baseline). Septic shock is defined as severe sepsis with hypotension despite adequate fluid resuscitation, which requires vasopressor support. MODS is defined as organ dysfunction in critically ill patients who require intervention to reach homeostasis. ${ }^{1}$

Activation of the inflammatory cascade by a new agent, with or without infection, seems to be self-sustained. ${ }^{3}$ However, resolution of the inducing agent cannot be the only treatment for SIRS and cannot break the progression of the inflammatory response that leads to MODS and death. Despite early administration of antibiotics, the progression of SIRS to sepsis, septic shock, MODS and death is sometimes unavoidable.

To lessen the progression of SIRS and improve the outcome, drugs such as glucocorticoids and anti-inflammatory nonsteroids have been used, albeit unsuccessfully. More recently, specific monoclonal antibodies against inflammatory cytokines such as tumor necrosis factor (TNF) have been tested. ${ }^{4}$

Glucocorticoids have an important immunosuppressive effect, in which they reduce the transcription of pro-inflammatory genes by inhibiting the nuclear factor kappa B. ${ }^{4-8}$ Several studies have involved the use of corticosteroids to reduce the systemic inflammatory process associated with the host response to sepsis and septic shock. ${ }^{9-21}$ However, most of these studies involved extremely high doses over short periods ( $<24$ hours), and no diagnostic criteria for sepsis were applied, because such criteria were not yet well-established at that time. The results were controversial, although some authors believed in the benefit of corticosteroids after observing early shock reversal or blood pressure elevation in treated patients. ${ }^{11,13,14,17,19,20,22,23}$

Some of these studies have not been confirmed by other groups. ${ }^{15}$ The results from two meta-analyses indicated no survival benefit when supraphysiological doses of corticosteroids were administered for short-term treatment of sepsis, and higher infection rates were associated with corticosteroids. ${ }^{12,18}$ Some authors ${ }^{16,24,25}$ believe that more careful, broader-scope studies are needed to conclusively identify the real benefits from these drugs.

Several reports have been published recently, from studies involving lower doses of hydrocortisone. These showed improved outcomes for patients with septic shock, and also showed that methylprednisolone could be used to obtain ARDS resolution. ${ }^{10,21,26,27}$ These recent results, as well as the unfavor- 
able results from using specific monoclonal antibodies, rekindle hope for the efficacy of corticosteroids in treating SIRS.

\section{口BJECTIVE}

This study aimed to evaluate the effectiveness of a single dose of dexamethasone in blocking the progression of SIRS.

\section{METHDDS}

This study was prospective, randomized, double-blind and placebo-controlled. After approval by a local ethics committee, informed consent was obtained from patients or from their next of kin prior to enrollment. ${ }^{28}$ Twentynine patients admitted into the postoperative intensive care unit (Surgical Support Unit, SSU) of Hospital das Clínicas, Universidade de São Paulo, took part in the study. Apart from these patients, one other patient was excluded after his next of kin withdrew their consent.

Patients with SIRS diagnosed 12 hours after SSU admission, ${ }^{1,29}$ with or without sepsis, were eligible for the study. Patients were excluded if they were under 18; had a history of immunosuppression therapy or a history of glucocorticoid use for over two weeks within the last year or upon admission to this hospital; were suffering from active pancreatitis; had a terminal illness (end-stage neoplasm with a life expectancy of less than three months); or had recently suffered gastrointestinal hemorrhage..$^{27}$ After SIRS diagnosis, blood, urinary and catheter-tip cultures (if infection was suspected) were obtained in accordance with the SSU hospital routine. A randomization table determined the order of inclusion for the patients to receive placebo, among the expected 30 admissions. All the eligible patients were prospectively randomized into two groups: Group D comprising 15 patients and Group P with 14 patients. Group D patients were given intravenous dexamethasone $0.2 \mathrm{mg} / \mathrm{kg}$ (in a single dose), ${ }^{30}$ while Group P patients received placebo ( $0.9 \%$ physiological saline solution).

Baseline severity of illness was assessed by means of the Acute Physiology and Chronic Health Evaluation II score (APACHE II). ${ }^{31,32}$ After SIRS diagnosis, the patients were assessed daily for seven consecutive days using the Sequential Organ Failure Assessment score (SOFA), ${ }^{33-37}$ or until their discharge from the SSU. Lactate and C-reactive protein plasma concentrations were also measured daily. ${ }^{38}$

The patients received conventional therapy regarding antibiotic regimens, serial blood cultures (whenever their body temperature was $>38^{\circ} \mathrm{C}$ ) and discharge criteria. Appropriate clinical and laboratory tests were conducted daily throughout the study. The subjects were evaluated during their stay in the SSU on the basis of the duration of vasopressor support (SOFA score of two or more for the cardiovascular system), mechanical ventilation and mortality.

Statistical analysis was performed using the Sigma Stat for Windows software, 2.03 version (SPSS Inc.). For continuous variables, the treatments were compared using the Student $t$ test, Mann-Whitney U test and two-way ANOVA (analysis of variance) for treatment and outcome conditions.

RESULTS

The mean age ( \pm standard deviation, $S D)$ of the 29 patients was $53 \pm 19$ years (range: 18 to 77 years). The study involved 19 males and 10 females $(66 \%$ versus $34 \%)$. The mean age $( \pm \mathrm{SD})$ for Group D was $51 \pm 22$ years, while the mean age for Group P was $54 \pm$ 14 years. There was no difference between these groups in relation to APACHE II $(15 \pm 5$ for Group D and $16 \pm 4$ for Group $\mathrm{P})$. At the baseline, the demographic characteristics and severity of disease were similar in the two groups (Table 1).

No statistical difference was found in either the mortality rates for the groups during the seven-day follow-up period (five deaths in Group D and three deaths in Group P; $p=0.682$; Fisher exact test), or in the blood, urinary or catheter-tip cultures. With regard to collateral effects from dexamethasone (increased glucose, secondary infections or gastrointestinal hemorrhage), only one patient in Group P developed gastrointestinal hemorrhage (patient 7 , with enterectomy due to intestinal perforation) while two patients in Group P developed pneumonia (patient 6, with colectomy due to neoplasia, and patient 7 , with aneurysm repair).

Among the 29 patients with SIRS, 14 failed to reach the SIRS criteria on the second day of their stay at the SSU. Eleven patients showed positive blood cultures, suggesting that these $38 \%$ of the patients had sepsis. Nine patients (31\%) had septic shock and the remaining 10 patients required vasopressor therapy during their SSU stay.

The two groups showed similar SOFA scores during the study. No differences were found in coagulation disorders (platelet counts), hepatic dysfunction (serum bilirubin), renal dysfunction (serum creatinine), or central nervous system dysfunction according to the Glasgow scale (Figure 1).

The respiratory system 24 hours after dexamethasone administration showed an improved $\mathrm{PaO}_{2} / \mathrm{FiO}_{2}$ ratio (Mann-Whitney test; $\mathrm{p}=0.017)$. However, this improvement did not persist throughout the study (Figure 2). The duration of mechanical ventilation was the same in the two groups $(3.26 \pm 2.46$ days for Group D and $3.64 \pm 3.15$ days for Group P).

Table 1. Baseline characteristics of the 29 patients with diagnosed systemic inflammatory response syndrome

\begin{tabular}{lcc}
\hline Characteristics & $\begin{array}{c}\text { Placebo Group } \\
(\mathbf{n}=14)\end{array}$ & $\begin{array}{c}\text { Dexamethasone Group } \\
(\mathbf{n}=15)\end{array}$ \\
\hline Age (years) & $54 \pm 14$ & $51 \pm 22$ \\
Male sex (\%) & 64.3 & 66.7 \\
Weight (kg) & 67.2 & 69.3 \\
APACHE II score & $16 \pm 4$ & $15 \pm 5$ \\
SOFA score & 6.9 & 7.1 \\
Prior or preexisting conditions (\%) & & \\
Hypertension & 28.6 & 33.3 \\
Myocardial infarction & 14.3 & 13.3 \\
Diabetes & 14.3 & 13.3 \\
Liver disease & 7.1 & - \\
COPD & 7.1 & 6.7 \\
Cancer & 21.4 & 20 \\
Recent trauma & 35.7 & 20 \\
Mechanical ventilation & 64.3 & 60 \\
Shock (use of any vasopressor) & 50 & 60 \\
\hline APACHE A A & & 6 \\
\hline
\end{tabular}

APACHE = Acute Physiology and Chronic Health Evaluation; SOFA = sequential organ failure assessment; COPD = chronic obstructive pulmonary disease. 


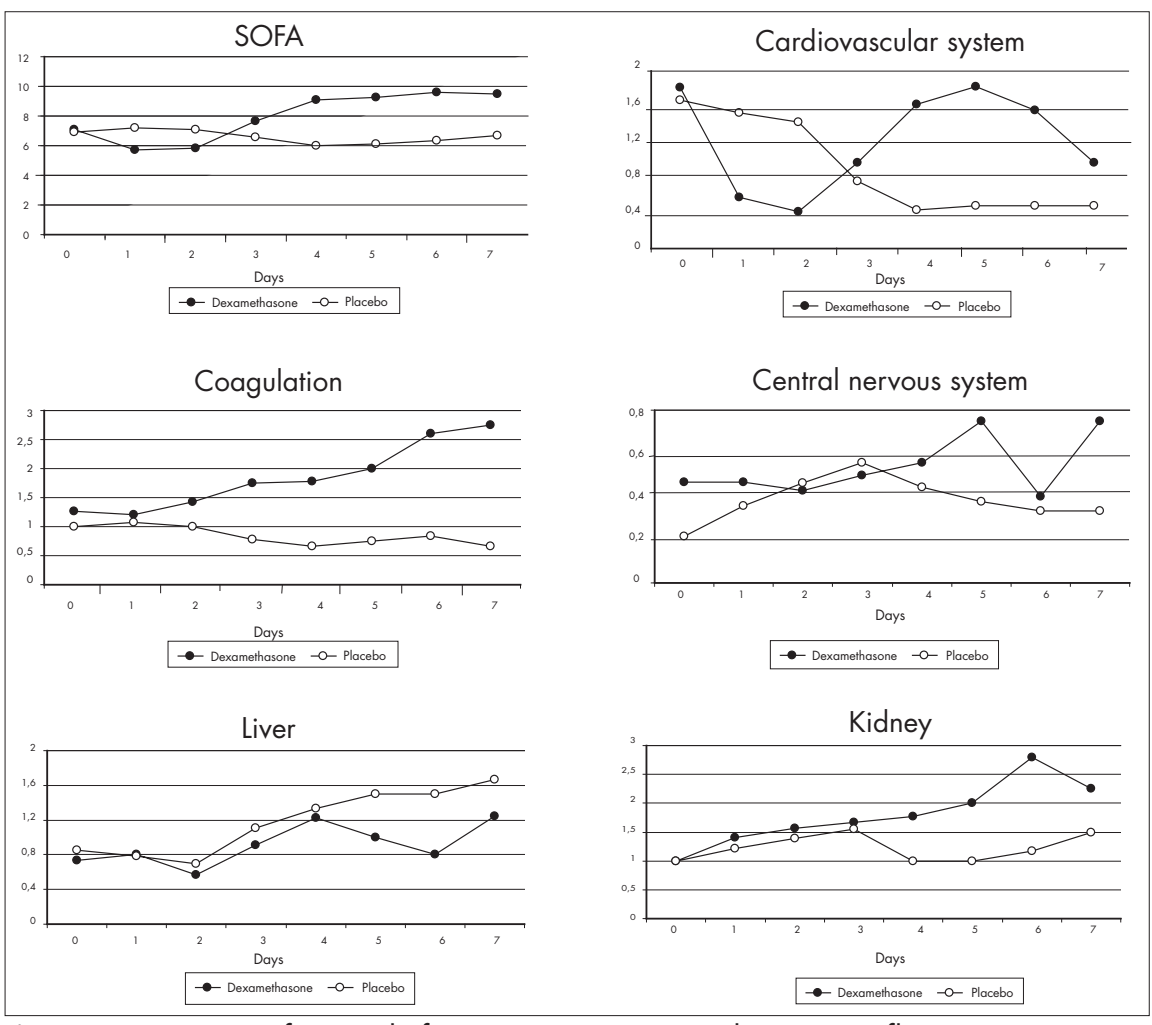

Figure 1. Progression of organ dysfunction in 29 patients with systemic inflammatory response syndrome, as assessed using the different components of the Sequential Organ Failure Assessment score (SOFA).

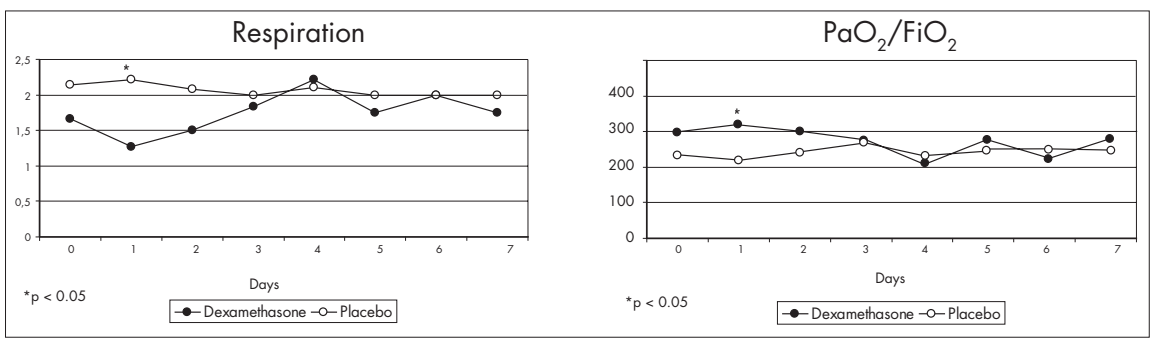

Figure 2. Improvement in the respiratory system and better evolution of the $\mathrm{PaO}_{2} / \mathrm{FiO}_{2}$ ratio in the first day after diagnosis of systemic inflammatory response syndrome in patients that received a single dose of dexamethasone, compared with those who received placebo.

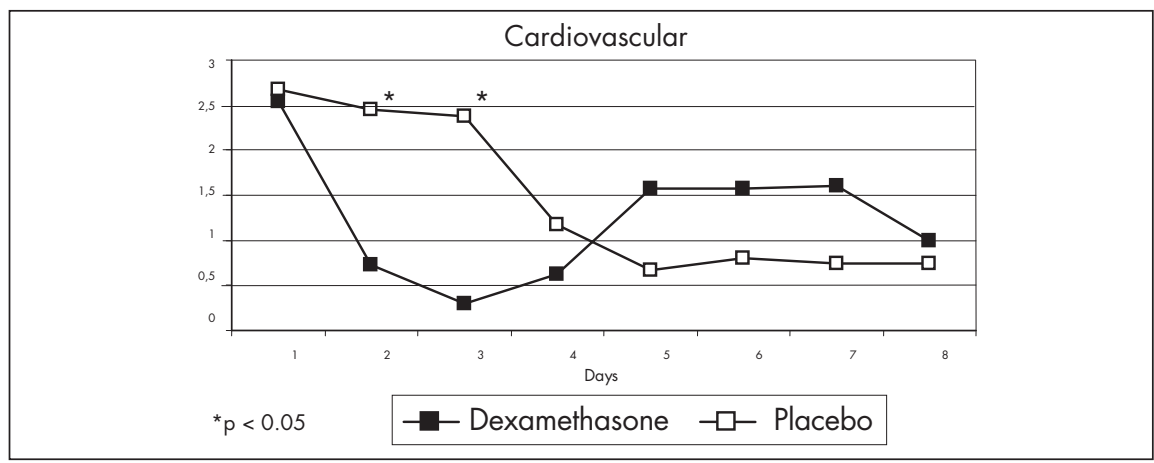

Figure 3. Improvement in the cardiovascular system during the first and second days after diagnosis of systemic inflammatory response syndrome in the group of patients that received a single dose of dexamethasone, compared with placebo, including only the patients that received vasopressor therapy.
The cardiovascular system score showed a trend towards improvement in Group D over the first two days (Figure 1). The better evolution in Group D, when the patients who did not receive vasopressor therapy were excluded (Mann-Whitney test; $\mathrm{p}=0.007$ and $\mathrm{p}$ $=0.018$ on days 1 and 2, respectively) (Figure 3 ), was noteworthy. However the duration of vasopressor therapy was statistically similar for the two groups $(2.2 \pm 2.1$ days for Group D and $2.8 \pm 1.9$ days for Group P).

All the 29 patients were also divided into two additional groups: survivors and non-survivors, in relation to the treatment. Eight patients $(27.6 \%)$ died during the seven-day period (SSU mortality). After using two-way ANOVA (analysis of variance) for the treatment, the cardiovascular system score was high for 48 hours among the non-survivors of Group P. In fact, these measurements displayed a significant difference $(\mathrm{p}=0.028$ on day one; $\mathrm{p}=0.003$ on day two). The respiratory system score showed the same pattern, i.e. it was low for 48 hours among survivors of Group D, with a significant difference $(p=0.0038$ on day one; $\mathrm{p}=0.008$ on day two).

Compared with the survivor group (21 patients), the non-survivors presented higher lactate assays (Mann-Whitney test; $\mathrm{p}=0.002$ ) for four days during the study (Figure 4).

$\mathrm{C}$-reactive protein was higher in the nonsurvivor group, starting on day three $(\mathrm{p}=0.028)$ and remaining high throughout (Figure 4). There was no difference between Groups D and $P$ relating to C-reactive protein.

Among the 29 patients studied, 17 patients (58.6\%) had suspected infection (nine patients in Group P and eight patients in Group D), and positive blood cultures were found in $11(37.9 \%)$ (six patients in Group P and five patients in Group D). Of the 29 patients, $12(41.3 \%)$ were given prophylactic antibiotics and five had to receive therapeutic antibiotics; 17 (58.6\%) received therapeutic antibiotics and three had to change antibiotics.

DISCUSSION

Despite recent studies in which patients with septic shock were treated with hydrocortisone, the present study has revealed some advantages in the use of dexamethasone ${ }^{39}$. This drug was chosen because of its potency and long-lasting action (36-48 hours), and its higher anti-inflammatory and lower mineralocorticoid effects. In comparison with hydrocortisone, dexamethasone causes no changes in sodium reabsorption and does not interfere in the water balance, thus avoiding 
hypervolemia and sodium disturbances. ${ }^{30} \mathrm{No}$ recent study was found involving the use of dexamethasone in SIRS or septic patients. All things considered, it seemed reasonable to test dexamethasone on the basis of a single dose, to investigate its benefits and observe any possible adverse effects.

The pathophysiology of sepsis includes host inflammatory response, endothelial damage, increased coagulation with decreasing fibrinolysis, fibroproliferation and microclot formation and relative adrenal insufficiency. ${ }^{40}$ However, this systemic inflammatory response can lead to organ dysfunction, instead of protecting and regulating homeostasis. ${ }^{40}$

Corticosteroids can improve the effects of vasopressor drugs, thus reestablishing receptor sensitivity, with better effects from the use of lower doses. ${ }^{23,26}$ The first explanation for the hemodynamic improvement of patients receiving corticosteroids was based on observations of the relative adrenal insufficiency that they might develop. ${ }^{23,25,41}$ In addition, some published reports have shown that patients without relative adrenal insufficiency could display better evolution following corticosteroid therapy. ${ }^{42,43}$ These reports may serve as backing for our finding of early discontinuation of vasopressor therapy in patients receiving dexamethasone.

Currently, the recommendations for corticosteroids in relation to sepsis are that this class of drugs should be used during refractory septic shock, but not during severe sepsis in the absence of shock or with mild shock. ${ }^{44}$ Whether or not sepsis is the systemic inflammatory response to infection, sepsis, severe sepsis and septic shock constitute different gradations in the continuum of a disease process. As this process continues, it is correlated with increasing organ dysfunction and mortality. Therefore, early infusion of corticosteroids to block this process that began with an inflammatory reaction ought to be tested.

The use of corticosteroids in septic patients can be explained by the relative adrenal insufficiency of these patients. However, it seems to us that the principal mechanism of action of corticosteroids is based on their anti-inflammatory effect.

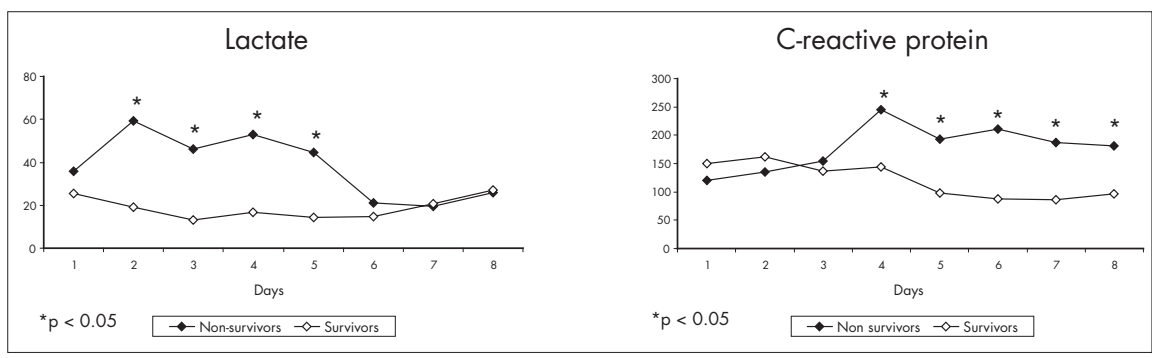

Figure 4. Evolution of lactate $(\mathrm{mg} / \mathrm{dl})$ and C-reactive protein $(\mu \mathrm{g} / \mathrm{ml})$ in the survivor and non-survivor groups of patients with systemic response syndrome.

An experimental study revealed that corticosteroids decreased pulmonary edema and collagen formation. ${ }^{45}$ Another study demonstrated an improvement in patients with ARDS after corticosteroid therapy, probably because of the inhibition of pulmonary fibroproliferation..$^{27,46}$ These previous studies support our observation that patients treated with dexamethasone displayed a better $\mathrm{PaO}_{2} / \mathrm{FiO}_{2}$ ratio on the first day after therapy. However, the use of corticosteroids for treating the early phase of ALI/ARDS has not been recommended (the recommendations include only the fibroproliferation phase). ${ }^{47}$ Nonetheless, even the patients in the present study who received dexamethasone during the early exudative phase (days 1-5) of ALI/ARDS showed an improved $\mathrm{PaO}_{2} / \mathrm{FiO}_{2}$ ratio. The rationale for this may include the observation that the integrity of the epithelial barrier in relation to the resolution of alveolar edema appears to be a determining factor in the outcome for ARDS patients. Patients who can concentrate the protein in the edematous fluid during the first 12 hours of illness are more likely to recover than those who cannot. Finally, since the change in the $\mathrm{PaO}_{2} / \mathrm{FiO}_{2}$ ratio following initial treatment of ARDS could pre-discriminate between survivors and non-survivors, ${ }^{47}$ the use of corticosteroids in the early phases of ALI/ARDS might be considered a reasonable step.

The arterial lactate assays for the survivor group went on decreasing from the first day of the study onwards. This result confirms previous findings that established that lactate is a good marker for septic patients. ${ }^{48}$
On the other hand, C-reactive protein did not appear to be a good marker for the patients' progression, since the non-survivor group showed higher values only after day 3 of the study. Evaluations of infected patients showed no increased levels of C-reactive protein, contrary to what was suggested by other authors. ${ }^{38,49-52}$ Our data cannot support the suggestion that C-reactive protein is a marker for infection. No correlation was observed between C-reactive protein values and the severity of infection or organ dysfunction level. ${ }^{53}$

This study remains part of an ongoing line of research, because of the significant results observed during the first two days after the single dexamethasone dose. Therefore, intravenous dexamethasone will be repeated at 48-hour intervals, to confirm the benefits for patients over a longer period, under closer assessment of their health status.

\section{CDNCLUSIONS}

Sepsis and acute lung injury can trigger an increased inflammatory response that appears to be attenuated by the administration of dexamethasone. SIRS treatment with corticosteroids may be not a simple resurrection of last rites, ${ }^{43}$ but a change in therapy that may have been used incorrectly in the past and may now get a fresh start based on new pathophysiological concepts regarding sepsis.

A single dose of dexamethasone enhanced the effects of vasopressor drugs for an apparently temporary period, and an evaluation of the respiratory system also revealed improvements, but it did not block the evolution of SIRS. 
1. Bone RC, Balk RA, Cerra FB, et al. Definitions for sepsis and organ failure and guidelines for the use of innovative therapies in sepsis. The ACCP/SCCM Consensus Conference Committee. American College of Chest Physicians/Society of Critical Care Medicine. Chest. 1992;101(6):1644-55.

2. Bone RC. Sepsis, sepsis syndrome, and systemic inflammatory response syndrome (SIRS). Gulliver in Laputa. JAMA. 1995;273(2):155-6.

3. Rangel-Frausto MS, Pittet D, Costigan M, Hwang T, Davis CS, Wenzel RP. The natural history of the systemic inflammatory response syndrome (SIRS). A prospective study. JAMA. 1995;273(2):117-23.

4. Christman JW, Lancaster LH, Blackwell TS. Nuclear facto kappa B: a pivotal role in the systemic inflammatory response syndrome and new target for therapy. Intensive Care Med. 1998;24(11):1131-8.

5. Janssen-Heininger YM, Poynter ME, Baeuerle PA. Recen advances towards understanding redox mechanisms in the activation of nuclear factor kappa B. Free Radic Biol Med. 2000;28(9):1317-27.

6. Scheinman RI, Cogswell PC, Lofquist AK, Baldwin AS Jr. Role of transcriptional activation of I kappa B alpha in mediation of immunosuppression by glucocorticoids. Science. 1995;270(5234):283-6.

7. Auphan N, DiDonato JA, Rosette C, Helmberg A, Karin M. Immunosuppression by glucocorticoids: inhibition of NF-kappa B activity through induction of I kappa B synthesis. Science. 1995;270(5234):286-90.

8. Bone RC. Toward a theory regarding the pathogenesis of the systemic inflammatory response syndrome: what we do and do not know about cytokine regulation. Crit Care Med. 1996;24(1):163-72.

9. Bihari DJ, Tinker J. Steroids in intensive care. Br J Hosp Med. 1982;28(4):323-4, 328-30.

10. Bollaert PE, Charpentier C, Levy B, Debouverie M, Audiber G, Larcan A. Reversal of late septic shock with supraphysiologic doses of hydrocortisone. Crit Care Med. 1998;26(4):645-50.

11. Schumer W. Controversy in shock research. Pro: The role of steroids in septic shock. Circ Shock. 1981;8(6):667-71.

12. Cronin L, Cook DJ, Carlet J, et al. Corticosteroid treatment for sepsis: a critical appraisal and meta-analysis of the literature. Crit Care Med. 1995;23(8):1430-9.

13. Demling RH, Smith M, Gunther R, Wandzilak T. Endotoxininduced lung injury in unanesthetized sheep: effect of methylprednisolone. Circ Shock. 1981;8(3):351-60.

14. Hughes GS Jr. Naloxone and methylprednisolone sodium succinate enhance sympathomedullary discharge in patients with septic shock. Life Sci. 1984;35(23):2319-26.

15. Kass EH. High-dose corticosteroids for septic shock. N Engl J Med. 1984;311(18):1178-9

16. Sheagren JN. Septic shock and corticosteroids. N Engl J Med. 1981;305(8):456-8.

17. Lederer V. Betamethasone sodium phosphate injection: highdose regimen in septic shock. Clin Ther. 1984;6(5):719-26.

18. Lefering R, Neugebauer E. Steroid controversy in sepsis and septic shock: a meta-analysis. Crit Care Med. 1995;23(7):1294303.

19. Nicholson DP. Corticosteroids in the treatment of septic shock and the adult respiratory distress syndrome. Med Clin North Am. 1983;67(3):717-24.

20. Ottosson J, Brandberg A, Erikson B, Hedman L, Dawidson I, Söderberg R. Experimental septic shock - effects of corticosteroids. Circ Shock. 1982;9(6):571-7.
21. Saito T, Takanashi M, Gallagher E, et al. Corticosteroid effect on early beta-adrenergic down-regulation during circulatory shock: hemodynamic study and beta-adrenergic receptor assay. Intensive Care Med. 1995;21(3):204-10.

22. Briegel J, Kellermann W, Forst H, et al. Low-dose hydrocortisone infusion attenuates the systemic inflammatory response syndrome. The Phospholipase A2 Study Group. Clin Investig. 1994;72(10):782-7.

23. Annane D, Sebille V, Charpentier C, et al. Effect of treatmen with low doses of hydrocortisone and fludrocortisone on mortality in patients with septic shock. JAMA. 2002;288(7):862-71

24. Carlet J. From mega to more reasonable doses of corticosteroids: a decade to recreate hope. Crit Care Med. 1999;27(4):672-4

25. Abraham E, Evans T. Corticosteroids and septic shock. JAMA. 2002;288(7):886-7.

26. Briegel J, Forst H, Haller M, et al. Stress doses of hydrocortisone reverse hyperdynamic septic shock: a prospective, randomized, double-blind, single-center study. Crit Care Med. 1999;27(4):723-32

27. Meduri GU, Headley AS, Golden E, et al. Effect of prolonged methylprednisolone therapy in unresolving acute respiratory distress syndrome: a randomized controlled trial. JAMA. 1998;280(2):159-65.

28. Reade MC, Young JD. Consent for observational studies in critical care: time to open Pandora’s Box. Anaesthesia. 2003;58(1):1-3.

29. Sibbald WJ, Doig G, Inman KJ. Sepsis, SIRS and infection Intensive Care Med. 1995;21(4):299-301.

30. Schimmer BP, Parker KL. Adrenocorticotropic hormone; adrenocortical steroids and their synthetic analogs; inhibitors of the synthesis and actions of adrenocortical hormones. In: Hardman JG, Gilman AG, Limbird LE, editors. Goodman \& Gilman's The Pharmacological Basis of Therapeutics. $9^{\text {th }}$ ed. St Louis: McGraw-Hill; 1996. p. 1459-85.

31. Cook R, Cook D, Tilley J, Lee K, Marshall J, Canadian Critical Care Trials Group. Multiple organ dysfunction: baseline and serial component scores. Crit Care Med. 2001;29(11):2046-50.

32. Muckart DJ, Bhagwanjee S. American College of Chest Physicians/Society of Critical Care Medicine Consensus Conference definitions of the systemic inflammatory response syndrome and allied disorders in relation to critically injured patients. Crit Care Med. 1997;25(11):1789-95.

33. Vincent JL, Moreno R, Takala J, et al. The SOFA (Sepsis-related Organ Failure Assessment) score to describe organ dysfunction/failure. On behalf of the Working Group on Sepsis-Related Problems of the European Society of Intensive Care Medicine. Intensive Care Med. 1996;22(7):707-10.

34. Vincent JL, de Mendonça A, Cantraine F, et al. Use of the SOFA score to assess the incidence of organ dysfunction/failure in intensive care units: results of a multicenter, prospective study. Working group on "sepsis-related problems" of the European Society on Intensive Care Medicine. Crit Care Med. 1998;26(11):1793-800.

35. Bernard GR. Quantification of organ dysfunction: seeking standardization. Crit Care Med. 1998;26(11):1767-8.

36. Timsit JF, Fosse JP, Troché G, et al. Calibration and discrimination by daily Logistic Organ Dysfunction scoring comparatively with daily Sequential Organ Failure Assessment scoring fo predicting hospital mortality in critically ill patients. Crit Care Med. 2002;30(9):2003-13.

37. Pettila V, Pettila M, Sarna S, Voutilainen P, Takkunen O Comparison of multiple organ dysfunction scores in the prediction of hospital mortality in the critically ill. Crit Care Med. 2002;30(8):1705-11
38. Póvoa P, Almeida E, Moreira P, et al. C-reactive protein as an indicator of sepsis. Intensive Care Med. 1998;24(10):1052-6.

39. Levy MM, Fink MP, Marshall JC, et al. 2001 SCCM/ESICM/ ACCP/ATS/SIS International Sepsis Definitions Conference. Intensive Care Med. 2003;29(4):530-8.

40. MacLaren R, Jung R. Stress-dose corticosteroid therapy for sepsis and acute lung injury or acute respiratory distress syndrome in critically ill adults. Pharmacotherapy. 2002;22(9):1140-56.

41. Manglik S, Flores E, Lubarsky L, Fernandez F, Chhibber VL Tayek JA. Glucocorticoid insufficiency in patients who present to the hospital with severe sepsis: a prospective clinical trial. Crit Care Med. 2003;31(6):1668-75.

42. Hotchkiss RS, Karl IE. The pathophysiology and treatment of sepsis. N Engl J Med. 2003;348(2):138-50.

43. Matot I, Sprung CL. Corticosteroids in septic shock: resurrection of the last rites? Crit Care Med. 1998;26(4):627-30.

44. Carlet J, International Sepsis Forum. Immunological therapy in sepsis: currently available. Intensive Care Med. 2001;27(Suppl 1):S93-103.

45. Meduri GU, Kanangat S. Glucocorticoid treatment of sepsis and acute respiratory distress syndrome: time for a critical reappraisal. Crit Care Med. 1998;26(4):630-3.

46. Thompson BT. Glucocorticoids and acute lung injury. Crit Care Med. 2003;31(4 Suppl):S253-7.

47. Martin GS, Bernard GR, International Sepsis Forum. Airway and lung in sepsis. Intensive Care Med. 2001;27(Suppl 1): S63-79.

48. Kobayashi S, Gando S, Morimoto Y, Nanzaki S, Kemmotsu O. Serial measurement of arterial lactate concentrations as a prognostic indicator in relation to the incidence of disseminated intravascular coagulation in patients with systemic inflammatory response syndrome. Surg Today. 2001;31(10):853-9.

49. Dinarello CA. The Acute-Phase response. In: Bennett JC, Plum F, editors. Cecil Textbook of Medicine. $20^{\text {th }}$ ed. Philadelphia: Saunders; 1996.p. 1567-9.

50. Reny JL, Vuagnat A, Ract C, Benoit MO, Safar M, Fagon JY Diagnosis and follow-up of infections in intensive care patients: value of $\mathrm{C}$-reactive protein compared with other clinical and biological variables. Crit Care Med. 2002;30(3):529-35.

51. Tschaikowsky K, Hedwig-Geissing M, Schiele A, Bremer F Schywalsky M, Schüttler J. Coincidence of pro- and anti-inflammatory responses in the early phase of severe sepsis: Longitudinal study of mononuclear histocompatibility leukocyte antigen-DR expression, procalcitonin, C-reactive protein, and changes in T-cell subsets in septic and postoperative patients. Crit Care Med. 2002;30(5):1015-23.

52. Soares AJ, David CMN. A avaliação do comportamento da proteína C-reativa em pacientes com sepse na UTI. Rev Bras Ter Intensiva. 2002;14(4):156-65.

53. Luzzani A, Polati E, Dorizzi R, Rungatscher A, Pavan R, Merlini A. Comparison of procalcitonin and C-reactive protein as markers of sepsis. Crit Care Med. 2003;31(6):1737-41.

Sources of funding: Not declared. Conflicts of interest: Not declared. Date of first submission: February 22, 2005

Last received: February 24, 2006

Accepted: February 24, 2006 


\section{AUTHLR INFLRMATILN}

Domingos Dias Cicarelli, MD. Attending physician, anesthesiologist in the Surgical Support Unit, Anesthesia Division, Department of Surgery, Hospital das Clínicas, Faculdade de Medicina, Universidade de São Paulo, São Paulo, Brazil.

Fábio Ely Martins Benseñor, MD, PhD. Attending physician, anesthesiologist, Supervisor of the Surgical Support Unit, Anesthesia Division, Department of Surgery, Hospital das Clínicas, Faculdade de Medicina, Universidade de São Paulo, São Paulo, Brazil.

Joaquim Edson Vieira, MD, PhD. Attending physician, anesthesiologist in the Surgical Support Unit, Anesthesia Division, Department of Surgery, Hospital das Clínicas, Faculdade de Medicina, Universidade de São Paulo, São Paulo, Brazil.

Address for correspondence:

Domingos Dias Cicarelli

Av. Piassanguaba, 2933 - Apto. 71

Planalto Paulista

São Paulo (SP) - Brasil

CEP 04060-004

Tel. (+55 11) 275-0569

E-mail: dcicarelli@uol.com.br

Copyright $\odot$ 2006, Associação Paulista de Medicina
RESUMロ

Efeitos da dexametasona em dose única em pacientes com síndrome da resposta inflamatória sistêmica

CONTEXTO E OBJETIVO: A síndrome da resposta inflamatória sistêmica (SRIS) acomete muitos pacientes internados em unidades de terapia intensiva. A evolução destes pacientes com SRIS para sepse, choque séptico e síndrome da disfunção de múltiplos órgãos (SDMO) pode conduzi-los rapidamente para o óbito. A proposta do trabalho é avaliar a eficácia da dexametasona em dose única como tratamento da SRIS.

TIPO DE ESTUDO E LOCAL: Estudo prospectivo, aleatório, duplamente encoberto, realizado na Unidade de Terapia Intensiva pós-operatória (Unidade de Apoio Cirúrgico) do Hospital das Clínicas da Faculdade de Medicina da Universidade de São Paulo.

MÉTODOS: Foram estudados 29 pacientes com diagnóstico de SRIS. Os participantes foram aleatoriamente divididos em dois grupos que receberam dexametasona $(0,2 \mathrm{mg} / \mathrm{kg}$ em dose única) ou placebo após o diagnóstico de SRIS. Os pacientes foram acompanhados durante sete dias de internação na UTI através do escore SOFA (Sequential Organ Failure Assessment).

RESULTADOS: Os pacientes que receberam dexametasona apresentaram melhora do sistema respiratório no primeiro dia, com aumento da relação $\mathrm{PaO}_{2} / \mathrm{FiO}_{2}(\mathrm{p}<0,05)$. Entre os pacientes que faziam uso de vasopressores, os que receberam dexametasona tiveram diminuição da necessidade destas medicações nos primeiros dois dias após a dose de dexametasona $(p<0,05)$.

CONCLUSÃO: A dexametasona diminuiu a necessidade de medicações vasopressoras e causou aumento da relação $\mathrm{PaO}_{2} / \mathrm{FiO}_{2}$ no primeiro dia após sua administração. Apesar destes efeitos, a dexametasona em dose única não bloqueou a evolução dos pacientes com SRIS

PALAVRAS-CHAVE: Síndrome séptica. Sepse. Inflamação. Corticosteróides. Dexametasona. 